\title{
XC. On the late solar eclipse
}

\section{E. Walker Esq.}

To cite this article: E. Walker Esq. (1816) XC. On the late solar eclipse, Philosophical Magazine Series 1, 48:224, 442-442, DOI: 10.1080/14786441608637707

To link to this article: http://dx.doi.org/10.1080/14786441608637707

$$
\text { 曲 Published online: } 27 \text { Jul } 2009 .
$$

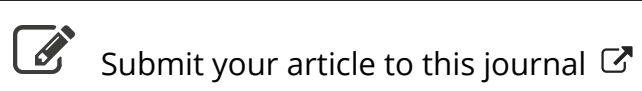

\footnotetext{
Џll Article views: 2
}

Q View related articles $\asymp$ 


\section{Inquiries into the Laws of Dilatation.of Solids, Liquids,}

on or near the meridian. But, if he will take the trouble to calculate the path of the moon's shadow, he will find that the sun was centrally eclipsed on the meridian in north latitude $43^{\circ}$ $8^{\prime} 48^{\prime \prime}$, east longitùde $29^{\circ} 41^{\prime} 30^{\prime \prime}$; and that the central path of the moon's shadow did not, at any time during its whole course, enter any part of the Russian territories.

$$
\text { I am, sir, }
$$

Your obedient servast,

London, Dec. 16, 1816.

Astronomictr.

XC. On the late Solar Eclipse. By E. WALKeR, Esg.

$$
\text { To Mr. Tilloch. }
$$

Dear Sir,- $T_{\text {HE following obserration on the solar eclipse, }}$ of November 19 , 1816, was taken in latitude $52^{2} 45^{\prime} 24^{\prime \prime} \mathrm{N}$. and longitude $1^{\prime} 34^{\prime \prime}, 4$ in time, east of Greenwich.

The beginning of the eclipse was not observed, but the end was taken, with a corcy-six inch achromatic magnifying fortytwo times, at $\quad . . \quad \quad \ldots \quad 10^{\mathrm{h}} 25^{\prime} 14^{\prime \prime}, 5$ A.M. per clock.

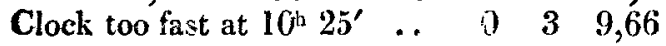

End of the aclipse $\quad . \quad \longdiv { 1 0 2 2 4 , 8 4 } \mathrm { m }$. time.

The air was very ciear during the time of observation, and the aperture of the oliject glass of the telescope being contracted to two inches, the distinciness graine by this means was more than a compensation for the low power i used. And, as I had an observation of the sun's transic over the meridian on the same day, the error of observation of the end of the eclipse does not, probably, amount to more tian a second.

$$
\begin{aligned}
& \text { I am, dear sir, } \\
& \text { Yynn, Dec. 10, 3816. } \\
& \text { Yours respectfully, } \\
& \text { Ez. WaLKER. }
\end{aligned}
$$

XCI. Inquiries into the Laws of Dilatation of Solids, Liquids, and elastic Fluids, and on the exact Measurement of Temperalures. By Messrs. Dulong and Petst. Read to the Institute 29 th of May 1816.

[Concluded from p. 380.]

\section{Of the Dilatation of Solids at high Temperatures,}

$T_{H E}$ knowledge of the dilatation of the metals, particularly of the duetile metals employed in the construction of instruments

and 